\title{
The influence of an extended Atlantic hurricane season on inland flooding potential in the southeastern United States
}

\author{
Monica H. Stone and Sagy Cohen \\ Department of Geography, The University of Alabama, Tuscaloosa, 35487-0322, USA \\ Correspondence to: Monica H. Stone (mhstone@ crimson.ua.edu)
}

Received: 29 September 2016 - Discussion started: 4 November 2016

Revised: 14 February 2017 - Accepted: 24 February 2017 - Published: 21 March 2017

\begin{abstract}
Recent tropical cyclones, like Hurricane Katrina, have been some of the worst the United States has experienced. Tropical cyclones are expected to intensify, bringing about $20 \%$ more precipitation, in the near future in response to global climate warming. Further, global climate warming may extend the hurricane season. This study focuses on four major river basins (Neches, Pearl, Mobile, and Roanoke) in the southeastern United States that are frequently impacted by tropical cyclones. An analysis of the timing of tropical cyclones that impact these river basins found that most occur during the low-discharge season and thus rarely produce riverine flooding conditions. However, an extension of the current hurricane season of June-November could encroach upon the high-discharge seasons in these basins, increasing the susceptibility for riverine hurricane-induced flooding. Our results indicate that $28-180 \%$ more days would be at risk of flooding from an average tropical cyclone with an extension of the hurricane season to May-December (just 2 months longer). Future research should aim to extend this analysis to all river basins in the United States that are impacted by tropical cyclones in order to provide a bigger picture of which areas are likely to experience the worst increases in flooding risk due to a probable extension of the hurricane season with expected global climate change in the near future.
\end{abstract}

\section{Introduction}

In the southeastern United States tropical cyclones are some of the most severe rain events (Schumacher and Johnson, 2006). While tropical cyclones occur less frequently than other rain-producing events, they cause the most damage be- cause they cover a large geographic area and often cause widespread flooding (Greenough et al., 2001; Mousavi et al., 2011; Schumacher and Johnson, 2006). On average, tropical cyclones occurring in the southeast bring $240.4 \mathrm{~mm}$ of rain in a $24 \mathrm{~h}$ period (Schumacher and Johnson, 2006). The severity of flooding following tropical cyclone events is a function of tropical storm frequency; landfall location; precipitation intensity; and, for coastal areas, mean sea level (Irish and Resio, 2013). In addition to flooding, these storms cause further damage from their strong winds (Greenough et al., 2001; Mousavi et al., 2011), and they frequently can cause tornadoes and landslides (Greenough et al., 2001; National Science Board (NSB), 2007).

Coastal communities in the United States, especially along the east coast and the Gulf Coast, are most at risk of the flooding, strong winds, and heavy precipitation associated with tropical cyclones (Irish et al., 2014). Approximately half of the United States population lives within only $\sim 80 \mathrm{~km}$ of the coast (NSB, 2007), and, on average, areas that are prone to tropical cyclones are 5 times more heavily populated than the rest of the nation (Frey et al., 2010). About 70 million people live in hurricane-prone areas (Greenough et al., 2001). Recent increases in coastal populations and development in coastal areas are posing an increasing risk to coastal infrastructure and human life (Greenough et al., 2001; Irish et al., 2014). Based off of 2010 estimates, $39 \%$ of US homes are located in coastal counties, an $8 \%$ increase since 2000 (NOAA, 2013). The monetary losses from hurricanes are increasing; in 2006 dollars, average annual losses were USD 1.3 billion from 1949 to 1989, USD 10.1 billion from 1990 to 1995, and USD 35.8 billion from 2002 to 2007 (NSB, 2007). Flooding from high storm surges during hurricanes has caused approximately 14600 deaths over the last cen- 
tury; about 50-100 deaths occur per hurricane event (Greenough et al., 2001). In addition to deaths caused by flooding, hurricanes can cause a variety of health impacts, including illnesses that result from ecological changes (changes in the abundance and distribution of disease-carrying insects, rodents, mold, and fungi), damage to healthcare infrastructure and reduced access to healthcare services, damage to water and sewage systems, overcrowded conditions in shelters, and psychological effects from the trauma faced by victims (Greenough et al., 2001).

Several studies have looked at the influence of tropical cyclones on river flooding in small catchments. Kostaschuk et al. (2001) investigated tropical-cyclone-induced flooding in the Rewa River system in Viti Levu, Fiji. They observed that rainstorms caused a higher number of floods but that floods caused by tropical cyclones were much larger (Kostaschuk et al., 2001). Waylen (1991) conducted a partial duration series flood analysis for the Santa Fe River in Florida and found similar results. Tropical-cyclone-induced floods were found to occur less often than floods from other rain-producing events. However, they tended to have larger magnitudes and longer durations (Waylen, 1991). Specifically, they found that tropical cyclone floods were $\sim 3$ times larger and $\sim 2$ times longer than other floods (Waylen, 1991).

Greenhouse gases in the atmosphere not only increase atmospheric temperature but also can lead to increased sea surface temperatures (Irish et al., 2014). The warmer the sea surface temperature, the greater the intensity of tropical cyclones. Thus, global warming may intensify tropical cyclones, such that storms may tend to have higher storm surge levels (Frey et al., 2010; Irish et al., 2014; Mousavi et al., 2011). The Intergovernmental Panel on Climate Change (IPCC) predicts that global sea surface temperatures will increase $1.1-6.4^{\circ} \mathrm{C}$ over the next century (Irish and Resio, 2013; Mousavi et al., 2011). Sea surface temperatures need to be at or above $\sim 26.7^{\circ} \mathrm{C}$ for tropical cyclones to form (Steenhof and Gough, 2008). The current hurricane season extends from June to November; however, longer seasons (i.e., storms occurring before June and/or after November) have been occurring in recent years (Dwyer et al., 2015). While research on this topic is not conclusive, there is some indication that global climate change may lead to a change in the Atlantic hurricane season (Dwyer et al., 2015). There is an $8 \%$ increase in a tropical cyclone's central pressure for each $1{ }^{\circ} \mathrm{C}$ increase in tropical sea surface temperature (Irish and Resio, 2013; Irish et al., 2014; Mousavi et al., 2011). Further, there is a $3.7 \%$ increase in a tropical cyclone's wind speed for each $1{ }^{\circ} \mathrm{C}$ increase in tropical sea surface temperature (Irish et al., 2014). Climate models also suggest that precipitation rates from tropical cyclones may increase by $20 \%$ by 2100 (Geophysical Fluid Dynamics Laboratory (GFDL), 2016; Knutson et al., 2010).

Numerous studies have indicated that global climate warming may intensify tropical cyclones and is very likely to result in sea level rise (Bronstert et al., 2002; Frey et al.,
2010; Greenough et al., 2001; Irish and Resio, 2013; Irish et al., 2014; Kostaschuk et al., 2001; Mousavi et al., 2011; Ouellet et al., 2012). Major hurricanes, those that are category 3 or higher on the Saffir-Simpson scale, are the most likely to intensify (Frey et al., 2010; Mousavi et al., 2011). However, there is some debate about changes in tropical cyclone frequency. Some research predicts that tropical cyclone frequency will increase (e.g., Greenough et al., 2001; Ouellet et al., 2012), while other research suggests that tropical cyclones are likely to intensify with global climate warming but occur less frequently (e.g., Irish and Resio, 2013; Kostaschuk et al., 2001).

Several studies about the effects of climate change on tropical cyclone intensity have been conducted for the Corpus Christi, TX area (Frey et al., 2010; Mousavi et al., 2011). Frey et al. (2010) determined how severe historical hurricanes would be if they were to occur in the current climate, and those predicted for the 2030s and 2080s. They found that, in all three climate scenarios, storm surge flood depth, area of flood inundation, population affected, and economic damages would all increase compared to the historical levels (Frey et al., 2010). In a follow-up study by Mousavi et al. (2011), sea level rise and tropical cyclone intensification, due to global warming, are likely to equally contribute to increased flood depths.

While there has been much focus on the impact of tropical cyclones on coastal flooding, there has been little research on how these high-intensity precipitation events affect the hydrology of streams just inland of coastal areas. Further, few studies have focused on how inland flooding is likely to be altered with an extended hurricane season in the near future due to likely global climate change. This study investigates the potential increase in flooding risk with an extension of the hurricane season on four rivers in the southeastern United States. The goal is to help determine how flooding potential may change in the near future in order to elucidate the impact such changes may have on communities in the southeastern United States.

\section{Study areas}

This research is focused on the southeastern United States, where tropical cyclone events occur quite frequently and where severe flooding following these events can have profound impacts on the prosperity of communities. Specifically, four river basins (Neches, Pearl, Mobile, and Roanoke) were selected for analysis (Fig. 1; Table 1). These four basins were chosen to be in areas that experience tropical cyclones and a high number of severe hurricanes. Currently, tropical cyclones impacting these four basins rarely cause flooding. As is shown later in this paper, this is primarily due to the overlap of the current hurricane season with the lowdischarge seasons on these four rivers. However, an extension of the hurricane season, such that it encroaches upon the 
Table 1. Gage location in and size of the four study basins.

\begin{tabular}{llrrl}
\hline River basin & Near & Latitude & Longitude & Basin size \\
\hline Neches & Silsbee/Evadale, TX & 30.374 & -94.094 & $25117 \mathrm{~km}^{2}$ \\
Pearl & Slidell, LA & 30.374 & -89.774 & $22894 \mathrm{~km}^{2}$ \\
Mobile & Mt. Vernon, AL & 31.094 & -87.974 & $110955 \mathrm{~km}^{2}$ \\
Roanoke & Williamston, NC & 35.864 & -76.904 & $25963 \mathrm{~km}^{2}$ \\
\hline
\end{tabular}

high-discharge seasons on these rivers, could likely lead to increases in flooding following tropical cyclones that impact these basins.

Gaging stations along these rivers were chosen to be inland of coastal areas so that tidal fluctuation and storm surge would not be factors when analyzing discharge, and far enough downstream to include as much of the basins as possible. These four basins were selected to represent a range of sizes and geographic locations that exist throughout the southeastern United States. United States Geological Survey (USGS) gages were used where data were available for the period extending from 1998 to 2014. In many cases (Pearl, Mobile, and Roanoke) USGS stream gages for these basins either did not have daily discharge data or did not have a long enough history of daily discharge data, or if sufficient daily discharge data were available, the location of the gaging station was either too close to the coast where there were tidal fluctuations or too far upstream in the catchment such that only a small fraction of the catchment was flowing to the gaging station. In these situations, Dartmouth Flood Observatory (DFO) satellite river gages were used (Brakenridge et al., 2016).

\section{Methods}

\subsection{Frequency and timing of tropical cyclones}

NOAA's Atlantic hurricane database (HURDAT2) (Landsea et al., 2015) was used to determine when tropical cyclones passed over the four basins. For each tropical cyclone event on record, this dataset provides information on the year, month, day, time, latitude, longitude, maximum sustained wind speed (in knots), minimum pressure (in millibars), and several wind speed radii extents for points along a tropical cyclone's track (where points are spaced at $6 \mathrm{~h}$ intervals). The data provided in the HURDAT2 dataset are downloadable in a text file format. A Python script was developed to extract this information in order to create point shapefiles of tropical cyclone paths that could be analyzed in GIS. The paths of tropical cyclones between 1998 and 2014 were buffered to a width of $300 \mathrm{mi}(\sim 500 \mathrm{~km})$, the average precipitation extent of a tropical cyclone (Darby et al., 2013). Then, a selectionby-location procedure was used to determine which buffered tropical cyclones passed over each of the basins. The coordinates of the buffered points along tropical cyclone paths passing over the basins were then used to look up the cor-

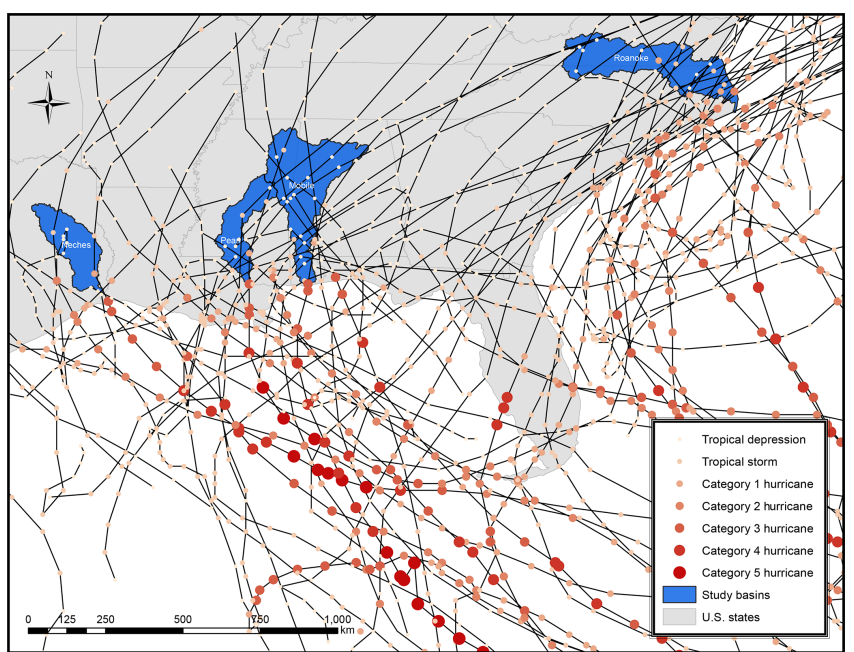

Figure 1. Location of the study basins analyzed in this study (blue); colored dots represent points along the tracks of all tropical cyclones since 1998 that have impacted the study basins, where the color/size of the dot indicates the severity of the storm at that location (see legend). (Hurricane track data were retrieved from NOAA's Atlantic hurricane database, HURDAT2 (Landsea et al., 2015); basin boundary data were retrieved from USGS's National Hydrography Dataset, NHD, and Watershed Boundary Dataset, WBD (USGS, 2016); basemap is from ESRI.)

responding dates each storm passed over each basin in the HURDAT2 dataset.

\subsection{Determining bankfull discharge}

Daily discharge data for the outlet of each of the basins over the period from 1998 to 2014 were obtained from either the USGS or the DFO's satellite river discharge measurements. The DFO sites provide daily measures of discharge beginning 1 January 1998 (Brakenridge et al., 2012). Discharge is estimated from NASA and the Japanese Space Agency TRMM microwave data (Brakenridge et al., 2012). This dataset is particularly useful because it allows the user to place gaging stations at any location along world rivers. Brakenridge et al. (2012) tested the accuracy of DFO satellite river discharge measurements and reported regression $r^{2}$ values $>0.6$. They also provide a site-specific "quality assessment" which, for sites in the United States, is based on calculating the Nash-Sutcliffe (NS) statistics for the DFO site and near gaging station hydrographs (Brakenridge et al., 2015). For the Mobile River site, for example, the DFO quality assessment ranking is 2 (fair), which means that the NS statistics were $>0.44$. However, since both bankfull and time series discharge are estimated from the same source in this study, while the absolute value may somewhat differ from the actual discharge, temporal trends and fluctuation magnitude were found to be well captured. This is clearly evident in 
(a)

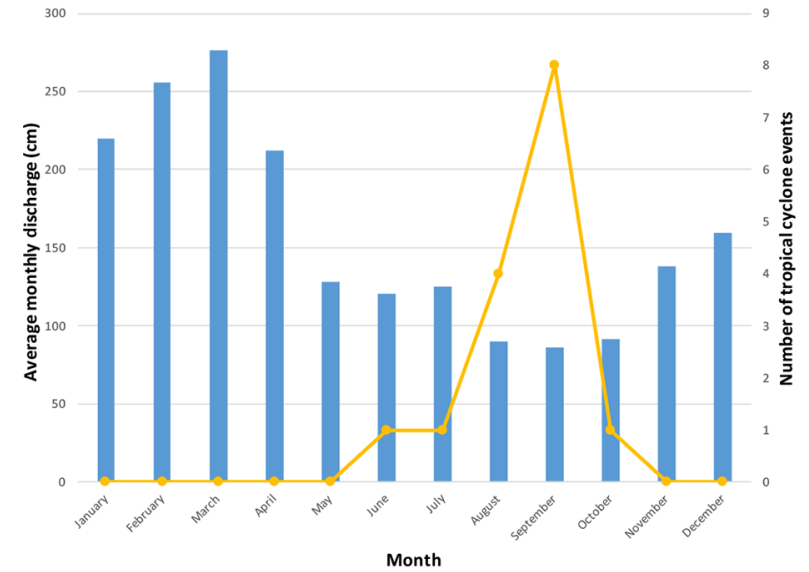

(c)

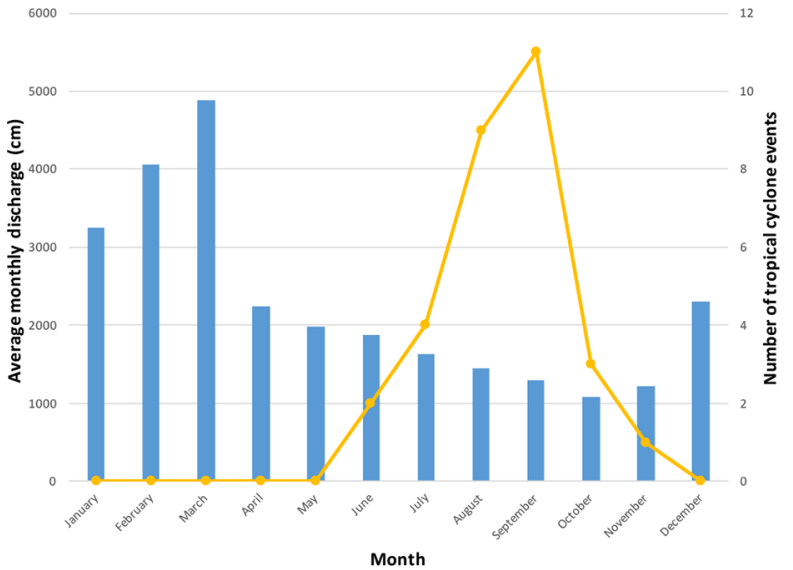

(b)

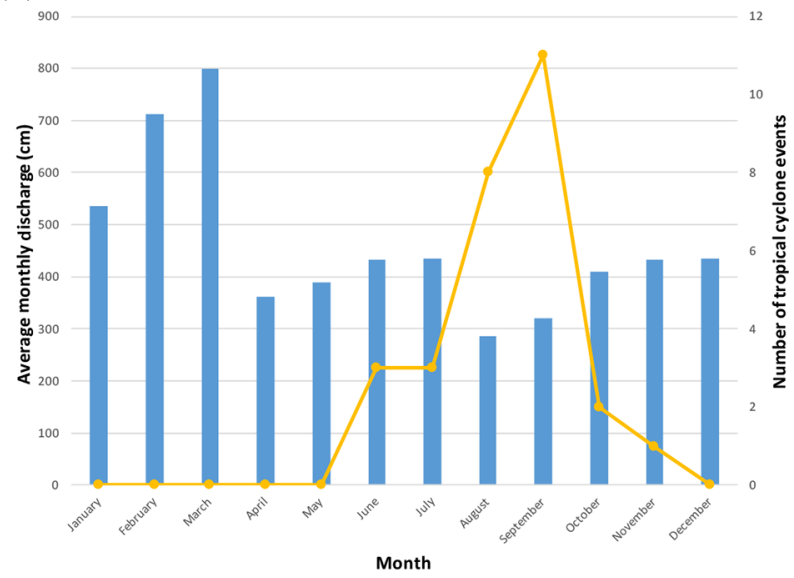

(d)

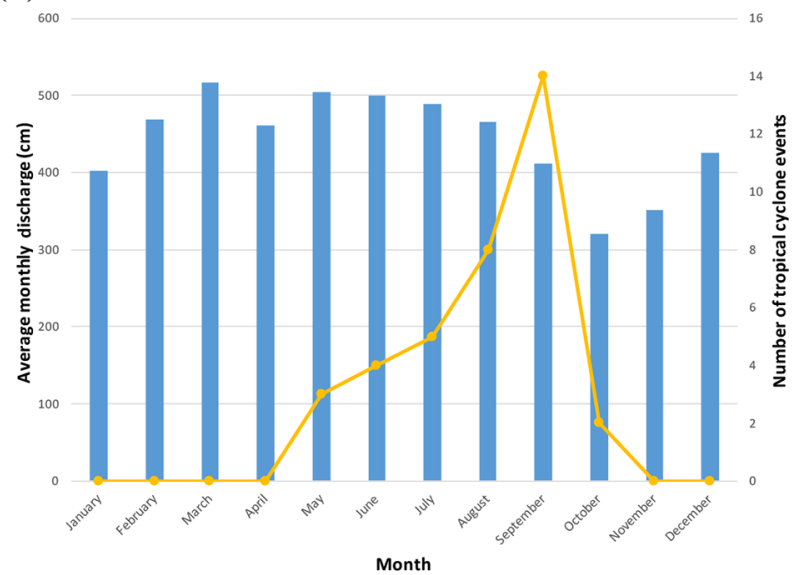

Figure 2. Comparison of average monthly discharge (blue bars) with the number of tropical cyclones occurring each month (yellow line) from 1998 to 2014 for the Neches (a), Pearl (b), Mobile (c), and Roanoke (d) basins.

the Mobile River DFO site (http://floodobservatory.colorado. edu/SiteDisplays/467.htm).

Using the daily discharge data obtained, the log Pearson type III statistic (Interagency Advisory Committee on Water Data (IACWD), 1982) was calculated for each basin. The log Pearson type III statistic can be used to provide an "industry standard" of bankfull discharge for a river at a particular gaging station; times when discharge is greater than the bankfull discharge indicate the occurrence of a flood (IACWD, 1982). In the study of tropical cyclone floods in Fiji by Kostaschuk et al. (2001), the log Pearson type III statistic was found to represent their partial duration flood series more accurately than the Pareto distribution, even though it tended to underestimate the largest flows slightly.

The log Pearson type III statistic was calculated using maximum yearly discharge values from 1998 to 2014:

$\log Q=\log \bar{Q}+K \sigma$ where $Q$ is the discharge of some return period, $\log \bar{Q}$ is the average of the $\log Q$ maximum discharge values, $K$ is the frequency factor (found using the $K$ frequency factor table, which is based upon return period and the skew coefficient), and $\sigma$ is the standard deviation of the $\log Q$ discharge values (Oregon State University (OSU), 2005). The variance can be found using Eq. (2):

$\sigma^{2}=\frac{\sum_{1}^{n}(\log Q-\log \bar{Q})^{2}}{n-1}$,

where $n$ is the number of maximum discharge values (i.e., the number of years) (OSU, 2005). The skew coefficient can be found using (OSU, 2005)

$C_{s}=\frac{n \sum(\log Q-\log \bar{Q})^{3}}{(n-1)(n-2)\left(\sigma^{3}\right)}$.

The bankfull discharge was calculated using a return period of 2.33, following Waylen (1991). 
(a)

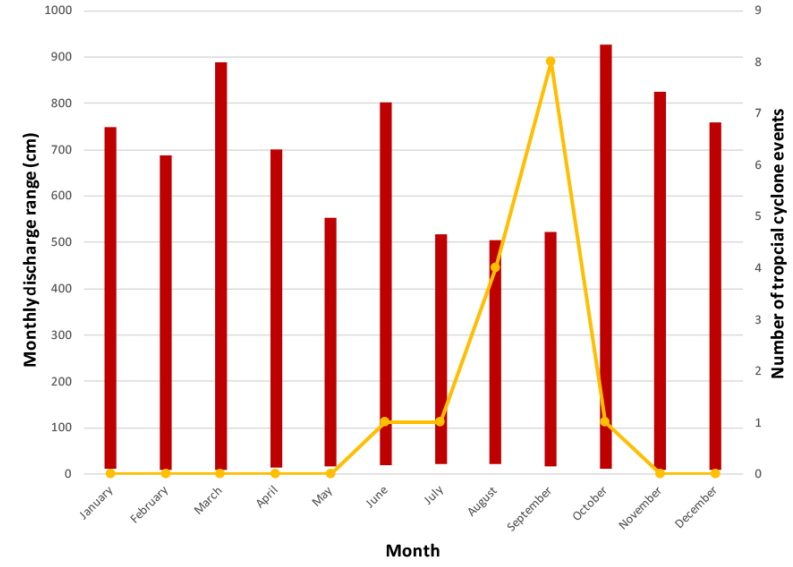

(c)

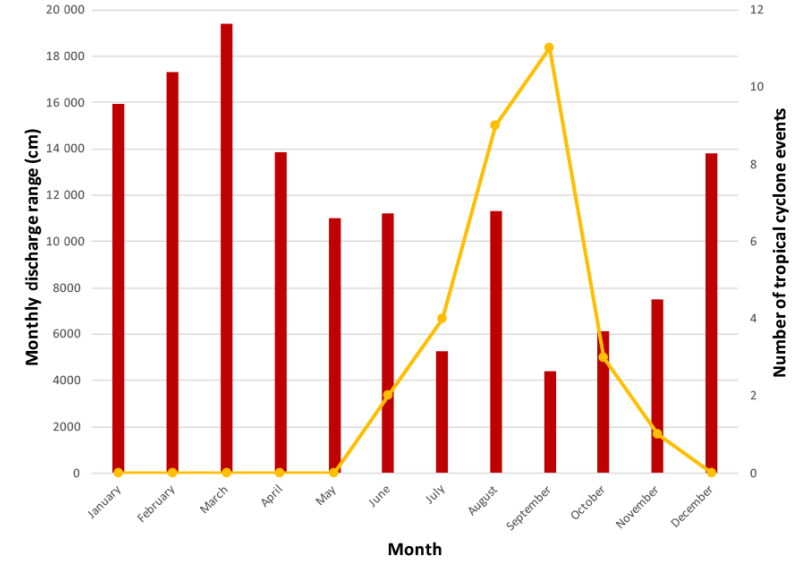

(b)

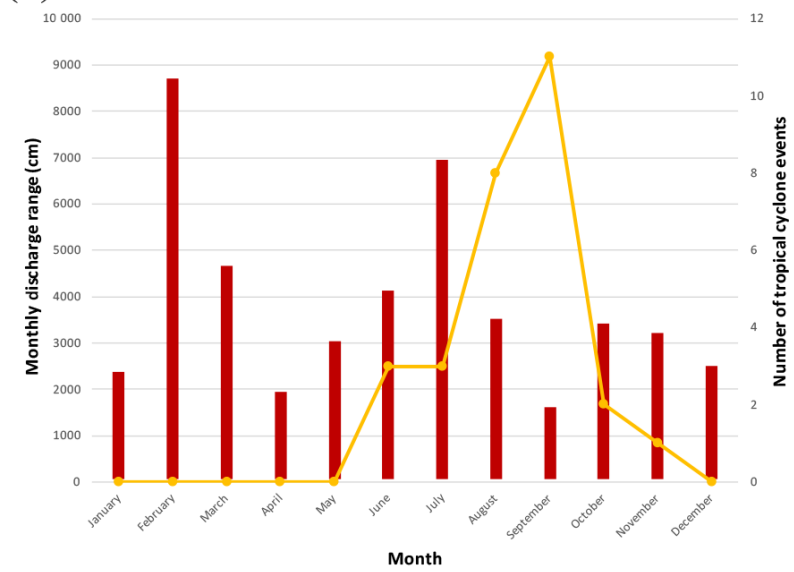

(d)

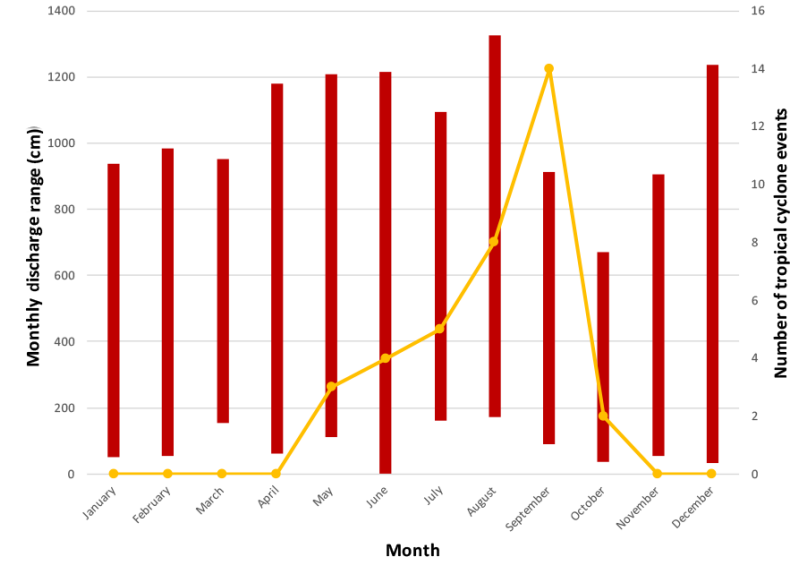

Figure 3. Comparison of monthly discharge maximum-minimum range (red bars) with the number of tropical cyclones occurring each month (yellow line) from 1998 to 2014 in the Neches (a), Pearl (b), Mobile (c), and Roanoke (d) basins.

\subsection{Analyzing the effects of an extended hurricane season on flooding susceptibility}

An analysis was performed to determine how many days from 1998 to 2014 during the hurricane season would have been at risk of flooding were an average tropical cyclone to have occurred on any given day. For each tropical cyclone in each basin from 1998 to 2014 the discharge the day before the event was compared to the peak discharge during the storm in order to determine the increases in discharge due to the tropical cyclones. For each basin, these increases in discharge were averaged to determine the average increase in discharge due to a tropical cyclone.

For each June-November day from 1998 to 2014, the daily discharge in the Neches River was increased by the average increase in discharge due to a tropical cyclone experienced by the Neches Basin. This increased discharge due to an average tropical cyclone was compared with the bankfull discharge value on each individual day for the Neches River.
A day with a discharge greater than bankfull discharge indicates that the Neches River likely would have flooded on this day if an average tropical cyclone were to have impacted this basin. Similar analyses were conducted for the Pearl, Mobile, and Roanoke basins.

The above methodology was then repeated with an extended Atlantic hurricane season of May-December. A 1month extension of the present June-November Atlantic hurricane season (Dwyer et al., 2015) was considered because several May (1 month outside the current hurricane season) tropical cyclones have impacted the Roanoke Basin in 2007, 2009, and 2012. The HURDAT2 dataset also indicates the occurrence of some May, as well as some December, Atlantic tropical cyclones. These data were then compared to the percentage of days susceptible to tropical-cyclone-induced flooding in the current hurricane season. 
(a)

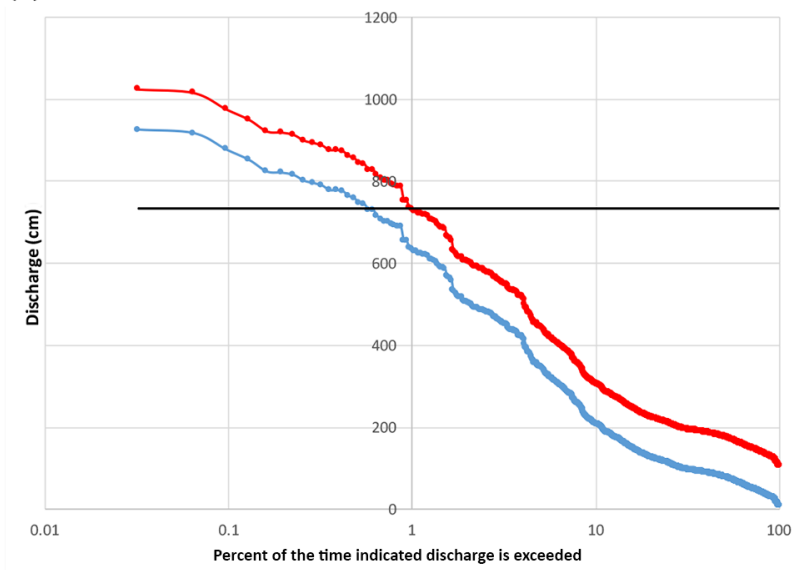

(c)

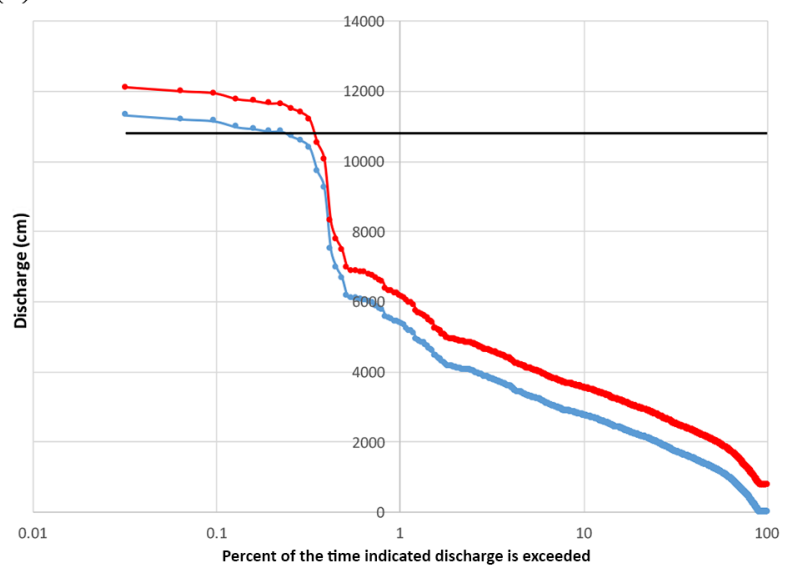

(b)

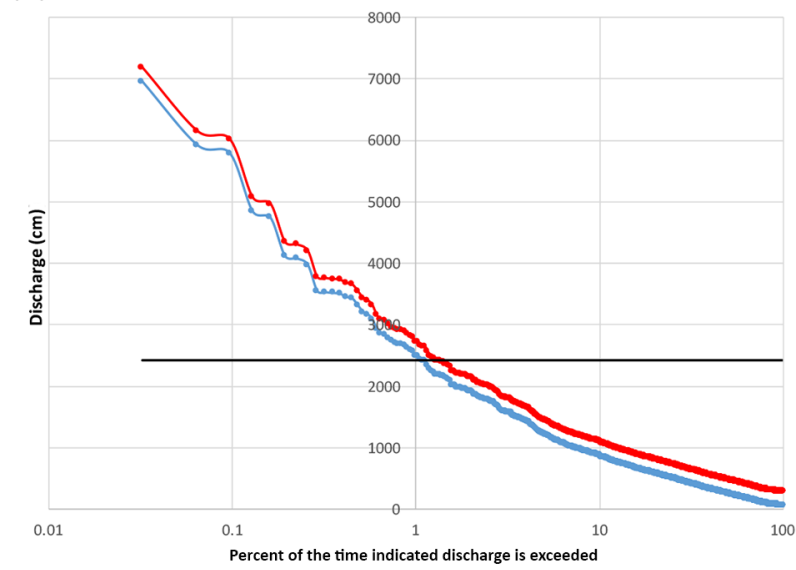

(d)

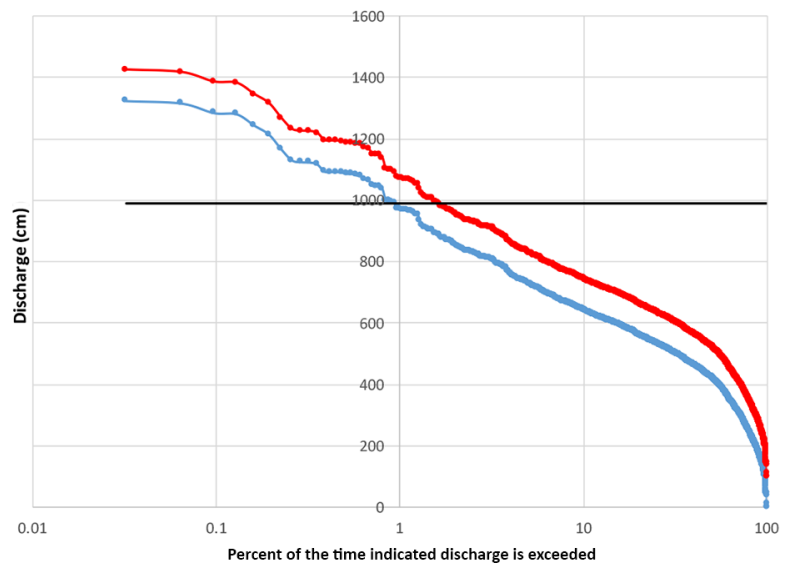

Figure 4. Bankfull discharge (black lines), flow duration curves (blue curves), and flow duration curves with discharge increased due to the average tropical cyclone (red curves) for the current hurricane season on the Neches (a), Pearl (b), Mobile (c), and Roanoke (d) rivers.

\section{Results}

\subsection{Tropical cyclone frequency and timing}

From 1998 to 2014 (17 years), 15 tropical cyclones impacted the Neches Basin, 28 impacted the Pearl Basin, 30 impacted the Mobile Basin, and 36 impacted the Roanoke Basin. The number of tropical cyclones impacting each basin each year has not been constant over the period of study. The years 2004 and 2005 had high numbers of storms in every basin, and in recent years there have been very few storms. For example, in 2004 and 2005 most basins experienced two or more tropical cyclones, while in 2013 and 2014 only the Roanoke Basin was impacted by tropical cyclones (and only one in each year). Most notably, almost all tropical cyclones impacting these four basins occur during low-discharge seasons, when flood risk is minimized (Figs. 2 and 3).

\subsection{Effects of an extended hurricane season on flooding susceptibility}

On average, tropical cyclones increased discharge (calculated from the difference between peak discharge and discharge the day before the storm) by $97.85 \mathrm{~m}^{3} \mathrm{~s}^{-1}$ on the Neches River, $226.71 \mathrm{~m}^{3} \mathrm{~s}^{-1}$ on the Pearl River, $787.25 \mathrm{~m}^{3} \mathrm{~s}^{-1}$ on the Mobile River, and $101.26 \mathrm{~m}^{3} \mathrm{~s}^{-1}$ on the Roanoke River (Table 2). The average percent increase in discharge following a tropical cyclone impact in all four rivers was $92 \%$ (Table 2).

The Roanoke River was the most susceptible to potential flooding from an average tropical cyclone in the current hurricane season scenario. On about 50 (out of 3111) days in the 1998-2014 June-November hurricane seasons the Roanoke River would be above bankfull discharge and at risk of flooding from an average tropical cyclone (Fig. 4d; Table 2). That is, about $1.61 \%$ of days would be susceptible to potential flooding were an average tropical cyclone to 
(a)

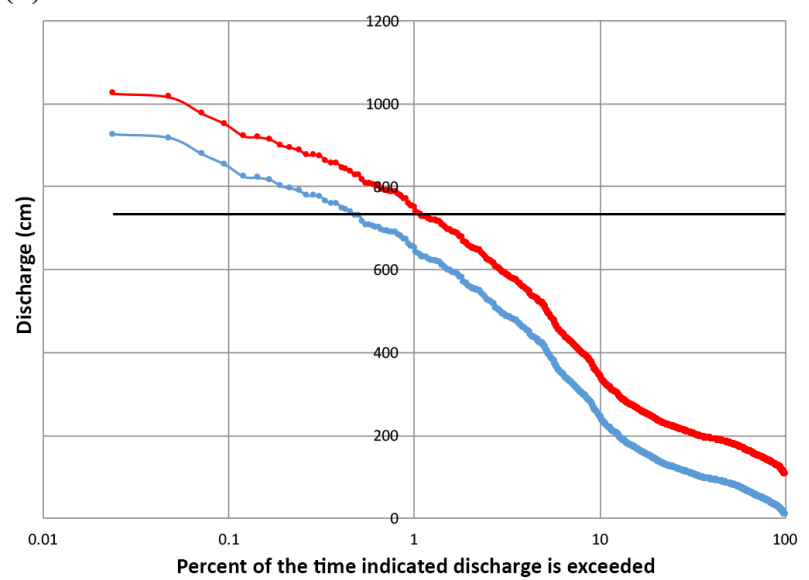

(c)

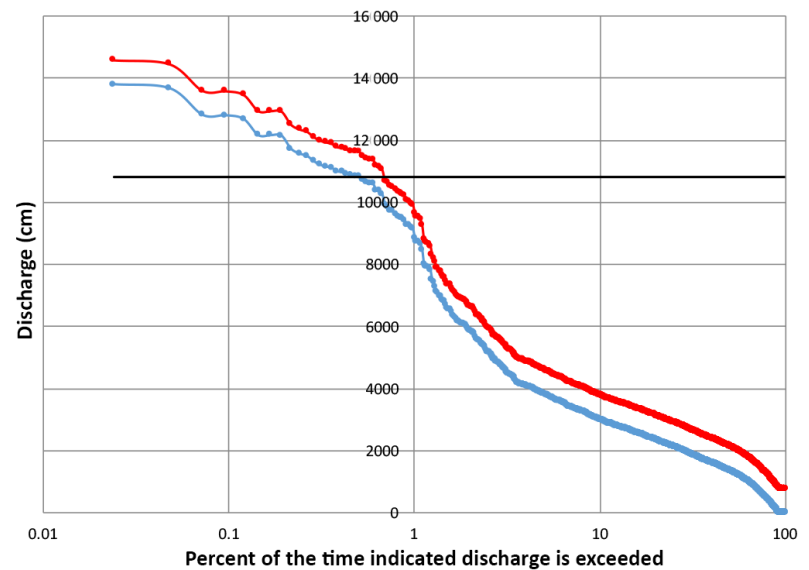

(b)

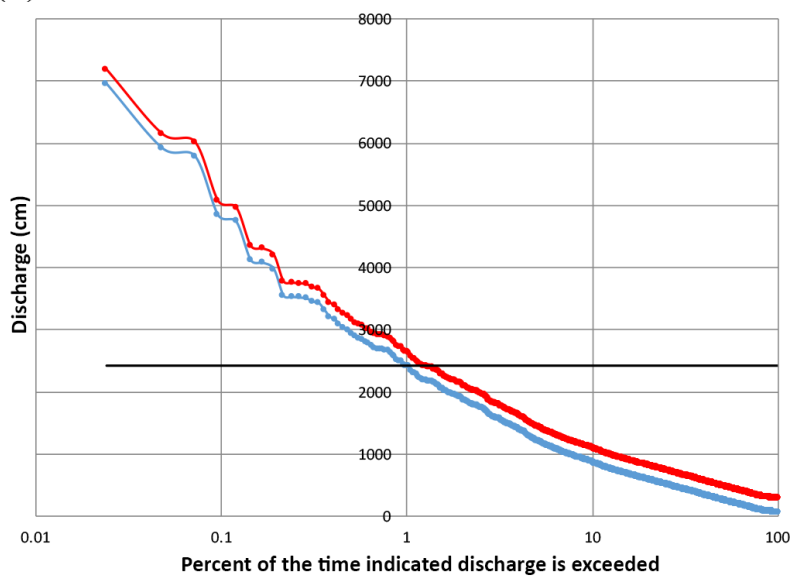

(d)

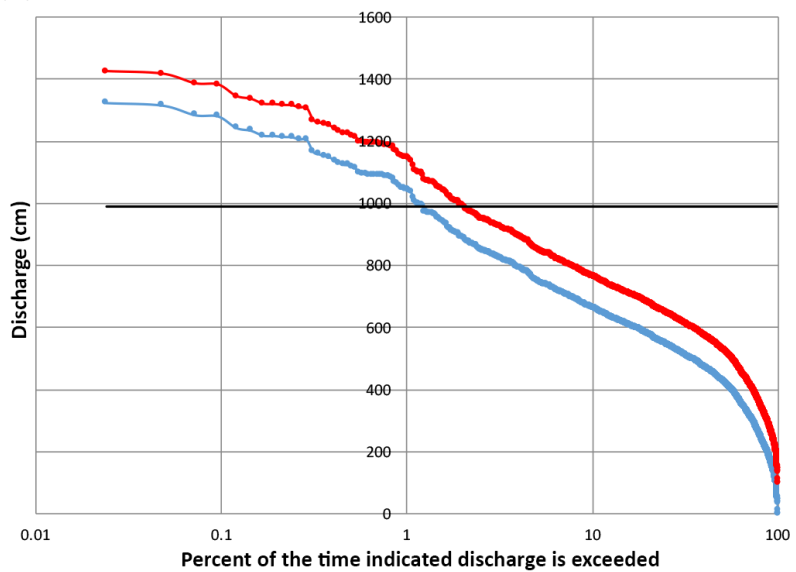

Figure 5. Bankfull discharge (black lines), flow duration curves (blue curves), and flow duration curves with discharge increased due to the average tropical cyclone (red curves) for an extended May-December hurricane season on the Neches (a), Pearl (b), Mobile (c), and Roanoke (d) rivers.

Table 2. Flooding risk from 1998 to 2014 for the four study basins with the current hurricane season and with an extended May-December hurricane season.

\begin{tabular}{|c|c|c|c|c|}
\hline Basin & $\begin{array}{l}\text { Increase in discharge } \\
\text { due to average } \\
\text { tropical cyclone }\end{array}$ & $\begin{array}{r}\text { Days at risk } \\
\text { with June-Nov season } \\
(\% \text { of time period })\end{array}$ & $\begin{array}{l}\text { Days at risk with } \\
\text { May-Dec season } \\
\text { (\% of time period) }\end{array}$ & $\begin{array}{l}\text { Increase in risk } \\
\text { with extended } \\
\text { season }\end{array}$ \\
\hline Neches & $97.85 \mathrm{~m}^{3} \mathrm{~s}^{-1}$ & $\begin{array}{r}30 \\
(0.96 \%)\end{array}$ & $\begin{array}{r}44 \\
(1.06 \%)\end{array}$ & $\begin{array}{l}+14 \text { days } \\
\text { (47\% increase) }\end{array}$ \\
\hline Pearl & $226.71 \mathrm{~m}^{3} \mathrm{~s}^{-1}$ & $\begin{array}{r}39 \\
(1.25 \%)\end{array}$ & $\begin{array}{r}50 \\
(1.20 \%)\end{array}$ & $\begin{array}{l}+11 \text { days } \\
\text { ( } 28 \% \text { increase })\end{array}$ \\
\hline Mobile & $787.25 \mathrm{~m}^{3} \mathrm{~s}^{-1}$ & $\begin{array}{r}10 \\
(0.32 \%)\end{array}$ & $\begin{array}{r}28 \\
(0.67 \%)\end{array}$ & $\begin{array}{l}+18 \text { days } \\
\text { (180\% increase) }\end{array}$ \\
\hline Roanoke & $101.26 \mathrm{~m}^{3} \mathrm{~s}^{-1}$ & $\begin{array}{r}50 \\
(1.61 \%)\end{array}$ & $\begin{array}{r}84 \\
(2.02 \%)\end{array}$ & $\begin{array}{l}+34 \text { days } \\
\text { (68\% increase) }\end{array}$ \\
\hline Average & $92 \%$ increase & $\begin{array}{r}32 \\
(1.04 \%)\end{array}$ & $\begin{array}{r}52 \\
(1.24 \%)\end{array}$ & $\begin{array}{l}63 \% \text { increase in \# } \\
\text { of days at risk }\end{array}$ \\
\hline
\end{tabular}


occur (Table 2). The Mobile River showed the least susceptibility with only about 10 days (or $0.32 \%$ of the time). The average susceptibility for potential tropical-cyclone-induced flooding for all four rivers was about 32 days (or $1.04 \%$ of the time) (Fig. 4; Table 2). The extended hurricane season showed greater flooding risk for all four of the rivers. Again, the flood risk was greatest on the Roanoke River ( 84 days, or $2.02 \%$ of the time) and least on the Mobile River (28 days, or $0.67 \%$ of the time) (Fig. 5; Table 2). On average, the extended hurricane scenario led to about 20 more days per basin that likely would be at risk of a flood were the average tropical cyclone to occur (Table 2). Over the 17 seasons, this is a $63 \%$ increase in the number of days at risk of flooding, or an increase from 1.9 to 3.1 days $\mathrm{yr}^{-1}$.

\section{Discussions and conclusions}

Most tropical cyclones impacting these four basins occur during September, or the middle of the low-discharge season (Figs. 2 and 3). The current hurricane season coincides primarily with the low-discharge seasons of the four basins. Thus, tropical cyclones rarely cause flood events on these rivers, even though they bring high amounts of precipitation, because they occur primarily during the low-discharge season. This is in contrast to tropical cyclones in Southeast Asia, for example, which are frequent during the monsoon season, causing widespread inland flooding (Darby et al., 2013). Some May tropical cyclones have already occurred in the Roanoke Basin during 2007, 2009, and 2012, and NOAA's HURDAT2 dataset contains other May and December tropical cyclones occurring in the Atlantic Ocean. This suggests that, while tropical cyclones rarely led to inland flooding from 1998 to 2014 in the four basins, a future extension of the hurricane season, such that it encroaches upon the highdischarge season in these rivers, has the potential to considerably enhance flooding risks.

Adding the months of May and December increases the number of days during the year that fall within the hurricane season by $34 \%$. For just a $34 \%$ increase in the length of the hurricane season, there was, on average, a $63 \%$ increase in the number of days at risk of a tropical-cyclone-induced flood along these southeast rivers (Table 2). When averaged over the 17-year period analyzed in this study, the number of days at risk of tropical-cyclone-induced flooding increases from 1.9 to 3.1 days $\mathrm{yr}^{-1}$. While 3 day $\mathrm{yr}^{-1}$ may not seem substantial, it not only represents a $63 \%$ increase, but it is also a conservative number, as it excludes predicted enhancements in the intensity and/or frequency of future tropical cyclones (Bronstert et al., 2002; Frey et al., 2010; Greenough et al., 2001; Irish and Resio, 2013; Irish et al., 2014; Kostaschuk et al., 2001; Mousavi et al., 2011; Ouellet et al., 2012). Further, this research does not consider synergistic effects due to the potential interplay between May and/or December tropi- cal cyclones and midlatitude cyclones, which could increase precipitation and flooding risk even further.

The timing of the hurricane season in relation to the highand low-discharge seasons is crucial to understanding flooding risk following tropical cyclones on these rivers. The Mobile and Roanoke rivers showed the greatest increase in flooding risk (68 and $180 \%$ respectively) in an extended May-December hurricane season as compared to the Neches and Pearl rivers (Table 2). The Pearl River showed the least increase in flooding risk following the average tropical cyclone $(28 \%)$ in an extended May-December hurricane season. While the Neches, Mobile, and Roanoke rivers tend to have slightly higher discharges in May than in June, discharges in the Pearl River are slightly lower in May than June. Thus, this study reveals not only that flooding risk following tropical cyclones is expected to increase if the hurricane season is extended due to global climate warming but also that this increase will not be uniform across the southeastern United States. Rivers with high-discharge seasons in May and December, such as the Mobile and Roanoke rivers, are likely to be most affected by a lengthened hurricane season.

The main limitation of this study is its use of average statistics. Future work could extend this study to look at increase in flood risk not only due to the average tropical cyclone but also due the full range of tropical cyclones that a basin is likely to experience (the tropical cyclone with the maximum increase in discharge, the tropical cyclone with the minimum increase in discharge, etc.). For instance, given that tropical cyclones are likely to intensify (Bronstert et al., 2002; Frey et al., 2010; Greenough et al., 2001; Irish and Resio, 2013; Irish et al., 2014; Kostaschuk et al., 2001; Mousavi et al., 2011; Ouellet et al., 2012), flooding risk in an extended hurricane season likely could exceed the results presented in this paper, although May and December tropical cyclones likely could be weaker than mid-season storms. Further, more explicit modeling of future tropical cyclone dynamics using a stochastic approach, rather than average statistics, could potentially produce a more robust understanding of the effects of future climate dynamics on flood susceptibility. Because the high-discharge season varies from basin to basin, extending this study to other basins along the east and Gulf coasts would allow for a fuller understanding of which areas in the southeastern United States are likely to be more at risk of flooding following tropical cyclones due to an extension of the hurricane season in response to global climate warming.

Data availability. The HURDAT2 dataset is available at http:// www.nhc.noaa.gov/data/. The DFO data is available at http:// floodobservatory.colorado.edu/DischargeAccess.html. The results of this study are not publicly available because they are being used in a follow-up study. 
Competing interests. The authors declare that they have no conflict of interest.

Acknowledgements. We wish to thank Jason Senkbeil and Peter Waylen for their guidance in this research. We are thankful for the help of G. Robert Brakenridge for his help in installing river gages for some of the study basins with the Dartmouth Flood Observatory. And lastly, thank you to The University of Alabama for funding portions of this research.

Edited by: T. Wagener

Reviewed by: two anonymous referees

\section{References}

Brakenridge, G. R., Cohen, S., Kettner, A. J., De Groeve, T., Nghiem, S. V., Syvitski, J. P. M., and Fekete, B. M.: Calibration of satellite measurements of river discharge using a global hydrology model, J. Hydrol., 475, 123-136, 2012.

Brakenridge, G. R., Kettner, A., Syvitski, J., Overeem, I., De Groeve, T., Cohen, S., and Nghiem, S. V.: Experimental satellite-based river discharge measurements: Technical summary, available at: http://floodobservatory.colorado.edu/ SatelliteGaugingSites/technical.html (last access: 1 September 2016), 2015.

Brakenridge, G. R., De Groeve, T., Kettner, A., Cohen, S., and Nghiem, S. V.: River Watch, Version 3, University of Colorado, Boulder, available at: http://floodobservatory.colorado. edu/DischargeAccess.html, last access: 1 September 2016.

Bronstert, A., Niehoff, D., and Büger, G.: Effects of climate and land-use change on storm runoff generation: Present knowledge and modeling capabilities, Hydrol. Process., 16, 509-529, 2002.

Darby, S. E., Leyland, J., Kummu, M., Räsänen, T. A., and Lauri, H.: Decoding the drivers of bank erosion on the Mekong river: The roles of the Asian monsoon, tropical storms, and snowmelt, Water Resour. Res., 49, 2146-2163, 2013.

Dwyer, J. G., Camargo, S. J., Sobel, A. H., Biasutti, M., Emanuel, K. A., Vecchi, G. A., Zhao, M., and Tippett, M. K.: Projected twenty-first century changes in the length of the tropical cyclone season, J. Climate, 28, 6181-6192, 2015.

Frey, A. E., Olivera, F., Irish, J. L., Dunkin, L. M., Kaihatu, J. M., Ferreira, C. M., and Edge, B. L.: Potential impact of climate change on hurricane flooding inundation, population affected, and property damages in Corpus Christi, J. Am. Water Resour. As., 46, 1049-1059, 2010.

Geophysical Fluid Dynamics Laboratory (GFDL): http://www.gfdl. noaa.gov/global-warming-and-hurricanes, last access: $23 \mathrm{Au}-$ gust 2016 .
Greenough, G., McGeehin, M., Bernard, S. M., Trtanj, J., Riad, J., and Engelber, D.: The potential impacts of climate variability and change on health impacts of extreme weather events in the United States, Environ. Health Persp., 109, 191-198, 2001.

Irish, J. L. and Resio, D. T.: Method for estimating future hurricane flood probabilities and associated uncertainty, J. Waterw. Port. C. Div., 139, 126-134, 2013.

Irish, J. L., Sleath, A., Cialone, M. A., Knutson, T. R., and Jensen, R. E.: Simulations of Hurricane Katrina (2005) under sea level and climate conditions for 1900, Climatic Change, 122, 635-649, 2014.

Interagency Advisory Committee on Water Data (IACWD): Guidelines for determining flood flow frequency (Bulletin \#17B), Hydrology Subcommittee, US Department of the Interior, Reston, VA, 1982.

Kostaschuk, R., Terry, J., and Raj, R.: Tropical cyclones and floods in Fiji, Hydrolog. Sci. J., 46, 435-450, 2001.

Knutson, T. R., McBride, J. L., Chan, J., Emanuel, K., Holland, G., Landsea, C., Held, I., Kossin, J. P., Srivastava, A. K., and Sugi, M.: Tropical cyclones and climate change, Nat. Geosci., 3, 157$163,2010$.

Landsea, C., Franklin, J., and Beven, J.: Atlantic hurricane database, available at: http://www.nhc.noaa.gov/data/ (last access: 1 September 2016), 2015.

Mousavi, M. E., Irish, J. L., Frey, A. E., Olivera, F., and Edge, B. L.: Global warming and hurricanes: the potential impact of hurricane intensification and sea level rise on coastal flooding, Climatic Change, 104, 575-597, 2011.

National Oceanic and Atmospheric Administration (NOAA): National coastal population report: Population trends from 19702020, Department of Commerce, 2013.

National Science Board (NSB): Hurricane warning: The critical need for a national hurricane research initiative, National Science Foundation, Arlington, VA, 2007.

Oregon State University (OSU): http://streamflow.engr.oregonstate. edu/analysis/floodfreq/, last access: 23 August 2016, 2005.

Ouellet, C., Saint-Laurent, D., and Normand, F.: Flood events and flood risk assessment in relation to climate and land-use changes: Saint-François River, Southern Québec, Canada, Hydrolog. Sci. J., 57, 313-325, 2012.

Schumacher, R. S. and Johnson, R. H.: Characteristics of U.S. extreme rain events during 1999-2003, Weather Forecast., 21, 6985, 2006.

Steenhof, P. A. and Gough, W. A.: The impact of tropical sea surface temperatures on various measures of Atlantic tropical cyclone activity, Theor. Appl. Climatol., 92, 249-255, 2008.

United States Geological Survey (USGS): Get NHD data, available at: https://nhd.usgs.gov/data.html, last access: 1 September 2016, 2016.

Waylen, P. R.: Modeling the effects of tropical cyclones on flooding in the Santa Fe river basin, Florida, GeoJ., 23, 361-373, 1991. 